\title{
HUBUNGAN PEMBERIAN INFORMED CONSENT DENGAN TINGKAT KEPUASAN KELUARGA PASIEN PRE OPERSI DI RUMAH SAKIT TINGKAT II PELAMONIA MAKASSAR
}

\author{
Satriana Dardi, Indah Mustikasari \\ STIKPER Gunung Sari Makassar
}

Alamat Korespondensi : (nhanatriyana87@gmail.com/081343958122)

\begin{abstract}
ABSTRAK
Tujuan dari penelitian ini adalah untuk mengetahui hubungan pemberian informed consent dengan tingkat kepuasan keluarga pasien pre operasi di Rs Tk II Pelamonia Makassar. Jenis penelitian yang digunakan adalah kuantitatif dengan desain penelitian deskriptif dengan menggunakan pendekatan cross sectional. Populasi dalam penelitian ini adalah seluruh pasien yang akan melakukan tindakan operasi (pre-operasi) RS TK. II Pelamonia Makassarberjumlah 65 orang pasien. sampel dalam penelitian ini adalah 39 orang pasien. Tehnik sampling yang digunakan dalam penelitian ini adalah Purposive Sampling. Data yang dikumpulkan menggunakan instrumen kuesioner dan dianalisis dengan menggunakan uji statistik Uji Chi-Square dengan derajat kemaknaan $(0,05)$. Berdasarkan hasil penelitian sebanyak 28 responden $(71,8 \%)$ pemberian informed consent dengan kategori baik. Sebagian besar sebanyak 32 responden $(82,1 \%)$ dengan kategori puas. Berdasarkan hasil analisis dengan menggunakan uji Chi-Square menyatakan bahwa nilai signifikansi yaitu 0,000 atau lebih kecil dari nilai signifikasi $0,05(0,000<0,005)$. Saran bagi peneliti yang akan melakukan penelitan: Sebagai proses pembelajaran untuk mengembangkan kemampuan dalam melakukan kajian-kajian ilmiah dibidang keperawatan dan Diharapkan agar hasil peneliti dapat dijadikan sebagai bahan informasi bagi institusi pendidikan.
\end{abstract}

\section{Kata Kunci : Pemberian Informed Consent, Tingkat Kepuasan, Keluarga Pasien}

\section{PENDAHULUAN}

Tindakan pembedahan merupakan salah satu bentuk terapi dan merupakan upaya yang mendatangkan ancaman terhadap tubuh, integritas dan jiwa seseorang. Tindakan pembedahan yang direncanakan dapat menimbulkan respon fisiologis dan psikologis pada pasien. Rentang respon akibat pembedahan tergantung pada individu, pengalaman masa lalu, pola koping, kekuatan dan keterbatasan. Pasien dan kelaurga memandang setiap tindakan sebagai peristiwa besar yang dapat menimbulkan takut dan cemas. Respon psikologis pada pasien dan kelaurga tergantung pada pengalaman masa lalu, strategis koping yang biasa digunakan, signifikan pembedahan serta sistem pendukung (Irwan, 2017).

Pada riset klinik terhadap manusia tidak boleh dilakukan tanpa persetujuan yang bersangkutan, setelah ia mendapat penjelasan. Apabila secara umum tidak mampu, persetujuan harus diperoleh dari walinya yang sah. Informed consent tidak hanya berpengaruh terhadap bidang riset atau penelitian klinis, tetapi juga terhadap tindakantindakan diagnosis dan terapeutik. Misalnya, sekarang banyak tindakan-tindakan diagnostik dan terapeutik yang tidak bisa ditebak akibatnya terhadap tubuh sehingga batas- batasnya tidak benar-benar tegas. Hal ini, membuat hubungan tenaga medis dengan pasien menjadi lebih kompleks (Cecep Triwibowo \& Yulia Fauziah, 2012)

Pelayanan keperawatan merupakan salah satu prioritas aspek yang perlu mendapat perhatian penting karena pelayanan keperawatan merupakan suatu pelayanan yang paling lama dan paling sering kontak dengan pasien. Kepuasan pasien akan menimbulkan kognisi, afeksi dan konasi yang baik terhadap pelayanan. Apabila pada pelanggan atau pasien sudah tumbuh kognisi, afeksi dan konasi yang baik maka minatnya untuk menggunakan jasa pelayanan akan timbul ( Muh Agung \& Muzakir, 2016).

Pelayanan kesehatan yang berkualitas serta menyatu dengan masyarakatnya sangatlah diperlukan di dunia kesehatan yang sekarang. Karena kesehatan merupakan bagian penting dalam pembangunan nasional, dengan tujuan utama menciptakan pola hidup masyarakat yang peduli, mengerti, dan tanggapan permasalahan kesehatan yang ada di lingkungan, dengan demikian diperlukan peningkatan kualitas dan kuantitas pelayanan kesehatan yang ada dari lembaga kesehatan. Kesehatan merupakan salah satu kebutuhan dasar manusia, sebagai kebutuhan yang mendasar, jadi setiap orang mengharapkan 
pelayanan kesehatan yang bermutu (Sri Purwati, 2017).

Kurangnya kepuasan pasien terjadi karena dinamika tuntutan pasien yang demikian cepatberubah namun tidak diimbangi dengan kecepatanperubahan pola kerja dan tindakan perawat.Perawat lebih banyak berfokus pada kinerja medikatau teknik keperawatan (pelaksanaan fungsi dependentatau fungsi pelimpahan dari dokter) padahal pasien nampaknya justru mengharapkan kinerja perawat sesuai normatifnya yaitu lebih berfokus pada aspek yang berkaitan dengan dimensi non teknik keperawatan (Kutri Riski dkk, 2015).

World health organization (WHO) telah mengenalkan Patient Safety Safe Surgery Saves Lives untuk meningkatkan keselamatan pasien pada pembedahan dunia dengan menyusun suatu standar yang dapat diaplikasikan pada semua negara. Sejak diluncurkannya Surgery Safety Checklist (SSC) WHO sampai saat ini, checklist ini sudah diadopsi oleh lebih dari 4000 rumah sakit didunia dari 122 negara, sedangkan pada level nasional, checklist ini sudah diadopsi oleh 25 negara ( WHO,2015).

Standar kepuasan pasien di pelayanan kesehatan ditetapkan secara nasional oleh Departemen Kesehatan. Menurut peraturan kementrian kesehatan republik indonesia tahun 2016 tentang standar pelayanan minimal untuk kepuasan pasien yaitu diatas $95 \%$. Bila mana ditemukan pelayanan kesehatan tingkat kepuasan pasien berada dibawah 95\%, maka dianggap pelayanan kesehatan yang diberikan tidak memenuhi standar minimal atau tidak berkualitas (Kemenkes, 2016).

Rumah Sakit TK II Pelamonia makassar adalah rumah sakit umum milik TNI AD dan merupakan rumah sakit tipe $B$ yang terletak di wilayah makassar, Sulawesi Selatan. Berdasarkan data yang diperoleh dari Rekam Medis RS TK II PELAMONIA MAKASSAR pada tahun 2016 jumlah pasien operasi mencapai 1351 dan pada tahun 2017 jumlah pasien operasi sebanyak 1263 dan pada tahun 2018 jumlah pasien operasi sebanyak 1056 sedangkan sebanyak 65 keluarga pasien yang mengalami kurang dengan tingkat kepuasannya.

Berdasarkan uraian di atas maka peneliti tertarik melakukan penelitian tentang hubungan pemberian informed consent dengan tingkat kepuasan keluarga pasien pra operasi di RS TK II Pelamonia Makassar.

\section{BAHAN DAN METODE}

Lokasi, Populasi, Sampel

Penelitian dilaksanakan pada bulan Juli 2019 di Rumah Sakit TK. II Pelamonia Makassar, Jl. Jend. Sudirman No.27, Pisang Utara, Ujung Pandang, Kota Makassar, Sulawesi Selatan. Populasi dalam penelitian ini adalah seluruh pasien yang akan melakukan tindakan operasi (pre-operasi) dan berada di ruang perawatan RS TK. II Pelamonia Makassar, antara januari - februari 2019 berjumlah 65 orang pasien.

\section{Pengumpulan Data}

1. Data primer

Data primer diperoleh dengan cara pertanyaan kepada responden sesuai dengan dafrar pertanyaan kepada responden sesui dengan daftar yang telah disusun dalam teks sekunder.

2. Data sekunder

Data sekunder diperoleh dari instutisi terkait, Rumah Sakit TK. II Pelamonia Makassar. berupa data laporan jumlah seluruh pasien pre-operasi.

\section{Pengolahan data}

Menurut Narbuko (2007) setelah datadata hasil dari kuesioner dikumpulkan dan diolah dengab melalui tahap-tahap :

1. Editing

Merupakan kegiatan untuk melakukan pengecekan kelengkapan data yang telah dikumpulkan.

2. Coding

Memberi kode pada data dengan merubah huruf menjadi angka.

3. Tabulating

Merupakan kegiatan menyusun data dalam bentuk tabel.

4. Entry data

Memasukkan data dengan cara manual atau melalui pengolahan program komputer.

5. Processing

Setelah semua terisi dengan benar langkah selanjutnya adalah memproses data agar dapat di analisa proses dan dilakukan dengan cara mengentry data dari kuesioner ke komputer dengan menggunakan SPSS.

\section{Analisa data}

1. Analisis Univariat

Analisa univariat adalah analisis yang dilakukan pada sebuah variabel. Dalam suatu penelitian, baik diperoleh melalui observasi, wawancara, kuesioner, maupun dokumentasi, analisis univariat dapat disajikan dalam bentuk : distribusi 
frekuensi, tendensi sentral dan nilai sebar dari variabel (Hasmi, 2016).

2. Analisis Bivariat

Analisa bivariate dilakukan untuk menjawab tujuan penelitian dan menguji hipotesis penelitian dengan menggunakan uji statistic chi-square dengan tingkat kemaknaan $\alpha=0,05$ pada program SPSS.

\section{HASIL PENELITIAN}

a. Analisis Univariat

Pemberian Informed Consent

Tabel 1. Distribusi Frekuensi Pemberian Informed Consent Rs TK II Pelamonia Makasaar

\begin{tabular}{|c|c|c|}
\hline Kategori & $\mathrm{n}$ & $\%$ \\
\hline $\begin{array}{c}\text { Pemberian Inforemd } \\
\text { Consent }\end{array}$ & 28 & 71,8 \\
\hline Baik & 11 & 28,2 \\
\hline Kurang Baik & 29 & 74,4 \\
\hline Kategori Sikap Perawat & 10 & 25,6 \\
\hline Baik & 32 & 82,1 \\
\hline $\begin{array}{c}\text { Kategori Tingkat Kepuasan } \\
\text { Keluarga Pasien Pre } \\
\text { Operasi }\end{array}$ & 7 & 17,9 \\
\hline Puas &
\end{tabular}

Sumber : Data Primer, 2019

Berdasarkan Tabel 1. diatas menunjukkan bahwa sebanyak 28 responden $(71,8 \%)$ pemberian informed consent dengan kategori baik dan sebanyak 11 responden $(28,2 \%)$ pemberian informed consent dengan kategori kurang. Sebanyak 29 responden $(74,4 \%)$ perawat dengan kategori sikap baik sedangkan sebanyak 10 responden $(25,6 \%)$ perawat dengan kategori sikap kurang. Sebanyak 32 responden $(82,1 \%)$ dengan kategori puas sedangkan sebanyak 7 responden (17,9\%) dengan kategori kurang puas.

b. Analisis Bivariat

Tabel 2. Hubungan Pemberian Informed Consent Dengan Tingkat Kepuasan Keluarga Pasien Pre OperasiRs TK II Pelamonia Makassar

\begin{tabular}{|c|c|c|c|c|c|c|}
\hline \multirow{3}{*}{$\begin{array}{c}\text { Pemberian } \\
\text { Informed } \\
\text { Consent }\end{array}$} & \multicolumn{4}{|c|}{$\begin{array}{c}\text { Tingkat Kepuasan } \\
\text { Keluarga Pasien Pre } \\
\text { Operasi }\end{array}$} & \multirow{2}{*}{\multicolumn{2}{|c|}{ Total }} \\
\hline & \multicolumn{2}{|c|}{ Puas } & \multicolumn{2}{|c|}{$\begin{array}{l}\text { Kurang } \\
\text { puas }\end{array}$} & & \\
\hline & $\mathrm{n}$ & $\%$ & $\mathrm{n}$ & $\%$ & $\mathrm{n}$ & $\%$ \\
\hline Baik & 28 & 79,5 & 0 & 0,0 & 28 & 71,8 \\
\hline Kurang & 4 & 36,4 & 7 & 63,6 & 11 & 28,2 \\
\hline Total & 32 & 82,1 & 7 & 17,9 & 39 & 100 \\
\hline
\end{tabular}

Sumber : Data Primer, 2019
Berdasarkan tabel $2 . \quad$ diatas menunjukkan bahwa pemberian informed consent pada keluarga pasien pre operasi di ruang perawatan Rs TK II Pelamonia Makassar didapatkan bahwa dari sebagian besar secara baik yakni 28 responden $(71,8 \%)$ diperoleh memiliki tingkat kepuasan baik pula yakni 32 responden $(82,1 \%)$ sementara dengan Pemberian Informed Consent kurang baik didapatkan 11 responden (28,2\%) dengan tingkat kepuasan kurang yaitu 7 responden $(17,9 \%)$.

Berdasarkan hasil analisis dengan menggunakan uji Chi-Square menyatakan bahwa nilai signifikansi yaitu 0,000 atau lebih kecil dari nilai signifikasi $0,05(0,000<0,005)$. Dari nilai kepuasan Kurang hanya $(17,9 \%)$ dengan menilai sikap perawat kurang $(25,6 \%)$. Berdasarkan hasil analisis dengan menggunakan uji Chi-Square menyatakan bahwa nilai signifikansi yaitu 0,000 atau lebih kecil dari nilai signifikasi $0,05(0,000<0,005)$. Dari nilai diatas maka dapat diambil kesimpulan yaitu $\mathrm{HO}$ ditolak atau terdapat hubungan sikap perawat dengan tingkat kepuasan keluarga pasien di RS TK II PELAMONIA MAKASSAR.

\section{PEMBAHASAN}

Pemberian Informed Consent

Hasil penelitian menunjukkan bahwa mayoritas sebanyak 28 responden (71,8\%) pemberian informed consent dengan kategori baik dan sebanyak 11 responden $(28,2)$ yang diberikan informed consent kurang.

Penelitian yang terkait dengan penelitian ini yaitu penelitian Tshimanga (2008) tentang Persepsi Pasien dan Pemahaman Informed Consent untuk Prosedur Pembedahan. Pasien yang memiliki pendidikan yang lebih tinggi menunjukkan pemahaman yang lebih akan persetujuan tindakan. Lebih dari $2 / 3 \%$ membutuhkan penjelasan yang lebih dalam bahasa ibu mereka untuk mengerti informasi tersebut $47 \%$ pasien tidak membaca formulir persetujuan tindakan. Deskripsi karakteristik berdasarkan tingkat pendidikan SMP 15,4\%, SMA 69,2\%, Sarjana 15,4\%. Dari hasil tersebut menunjukkan bahwa tingkat pendidikan juga mempengaruhi pemahaman tentang proses informed consent yang akan diberikan.

1. Sikap Perawat

Penilaian sikap perawat dalam penilitian peneliti menggunakan kuesioner yang berisi 10 (sepuluh) peryataan. Masing-masing pernyataan diberikan pilihan jaawaban, yaitu Baik dan Kurang Baik. Hasil penilaian responden tentang sikap perawat diperoleh hasil sebagai 
berikut: $74,4 \%$ responden menilai sikap perawat Baik dan 25,6\% responden menilai sikap perawat Kurang Baik. Dengan demikian dapat dikatakan bahwa mayoritas responden menilai sikap perawat Rs TK II Pelamonia Makassar termasuk dalam kategori baik $(74,4 \%)$.

Berdasarkan jawaban responden tersebut ternyata terdapat $25,6 \%$ responden yang menilai bahwa sikap perawat dinilai kurang baik. Berdasarkan data jawaban responden diperoleh beberapa hal yang dinilai masih kurang oleh responden, yaitu: kebersihan, perlengkapan yang digunakan oleh perawat, seperti: sarung tangan dan masker, pengetahuan perawat dalam memahami pekerjaan dengan baik, perawat perlu lebih berani untuk memberikan teguran pada tamu yang berisik saat berkunjung, perawat perlu memperhatikan sikapnya untuk tidak membedakan pelayanan pada setiap pasein dan kemampuan perawat dalam memberikan motivasi kepada pasien untuk mampu bersosialisasi dengan masyarakat.

2. Tingkat Kepuasan Keluarga Pasien pre operasi

Penilaian tingkat kepuasan keluarga pasien pre operasi dalam penilitian peneliti menggunakan kuesioner yang berisi 10 (sepuluh) peryataan. Masing-masing pernyaan diberikan pilihan jaawaban, yaitu Baik dan Kurang Baik. Hasil penilaian responden tentang tingkat kepuasan diperoleh hasil sebagai berikut: $82,1 \%$ responden menilai tingkat kepuasan Puas dan $17,9 \%$ responden menilai tingkat kepuasan Kurang puas. Dengan demikian dapat dikatakan bahwa mayoritas responden menilai tingkat kepuasan Rs TK II Pelamonia Makassar termasuk dalam kategori baik $(82,1 \%)$.

Hasil pengisian data oleh responden tentang tingkat kepuasan diperoleh hasil sebagai berikut: $82,1 \%$ responden menilai tingkat kepuasan Puas dan 17,9\% responden menilai tingkat kepuasan Kurang puas. Berdasarkan data tersebut dapat dikatakan bahwa pada dasarnya mayoritas responden telahm merasa puas, namun masih terdapat responden yang merasa tidak puas tentang kemampuan perawat dalam memberikan pelayanan. Akibat dari tidak puas tersebut responden merasa bahwa Perawat tidak bersikap simpatik dan menyakinakn dalam menghadapi masalah pasien.

Kepuasan pasien merupakan reaksi perilaku sesudah menerima pelayanan/penerapan kesehatan. Hal ini mempengaruhi pengambilan keputusan pemanfaatan ulang yang sifatnya terusmenerus terhadap pembelian jasa yang sama dan akan mempengaruhi penyampaian pesan/kesan kepada pihak/orang lain tentang penerapan kesehatan yang diberikan (Azwar, 2005).

Penjelasan tentang kepuasan pasien tersebut di atas menunjukkan bahwa kepuasan pasien merupakan hal yang sangat penting sebab terbentuknya kepuasan keluarga pasien akan menentukan berbagai hal yang terwujud dari perilaku pasien, seperti: hubungan pasien dengan RS, kemauan pasien untuk kembali di rwat jika sakit, loyalitas pasien pada RS, dan menjadikan pasein untuk bersedia merekomendasiakan pengobatan di RS dengan orang lain.

\section{Analisis Bivariat}

1. Hubungan Pemberian Informed Consent Dengan Tingkat Kepuasan Keluarga Pasien Pre OperasiRs TK II Pelamonia Makassar

Informed Consent adalah tindakan yang diberikan oleh perawat sebelum klien menandatangani formulir persetujuan dengan memberikan penjelasan tentang prosedur, manfaat tindakan dan komplikasi tindakan.

Berdasarkan data analisis univariat diperoleh, dari 39 responden menunjukkan bahwa pemberian informed consent pada keluarga pasien pre operasi di ruang perawatan Rs TK II Pelamonia Makassar didapati bahwa dari sebagian besar secara baik yakni 28 responden $(71,8 \%)$ dengan memiliki tingkat kepuasan baik pula yakni 32 responden $(82,1)$ sementara dengan Pemberian Informed Consent kurang baik didapati 11 responden $(28,2 \%)$ dengan tingkat kepuasan kurang yaitu 7 responden $(17,9)$. Hasil analisis data dengan menggunakan independent sample $t$ test antara pemberian informed consent dengan tingkat kepuasan di dapat $p$-valeu= 0,000 . $\quad(p<0,05)$ maka dapat di intreprestasikan bahwa ada faktor yang berhubungan signifikan antara pemberian informed consent dengan tingkat kepuasan keluarga pasien pre operasi di Rs TK II Pelamonia Makassar.

Informed Consent adalah persetujuan yang diberikan oleh pasien atau walinya yang berhak kepada dokter untuk melakukan suatu tindakan medis terhadap pasien sesudah pasien atau wali itu memperoleh informasi lengkap dan 
memahami tindakan itu (Suprapti, 2001 dikutip oleh Matri, 2013).

Informed Consent adalah melndungi pasien terhadap segala tindakan medis yang dilakukan tanpa sepengetahuan pasein, memberikan perlindungan hukum kepada dokter terhadap akibat yang tidak diduga dan bersifat negatif. Memberikan penjelasan kepada pasien dalam melakukan tindakan medik mempunyai tujuan mengurangi ketakutan pasien, penjelasan yang diberikan bertujuan menghindari akibat resiko tindakan pembedahan rerhadap pasien yang terduga.

Tujuan dasar dari informed consent adalah untuk melindungi otonomi pasien sebagai manusia dan sebagai ungkapan rasa hormat kepada pasien untuk menentukan pilihan secara bebas dan bebas memilih yang terbaik untuk dirinya.

Penelitian yang terkait dengan penelitian ini yaitu penelitian Tshimanga (2015) tentang Persepsi Pasien dan Pemahaman Informed Consent untuk Prosedur Pembedahan. Pasien yang memiliki pendidikan yang lebih tinggi menunjukkan pemahaman yang lebih akan persetujuan tindakan. Lebih dari 2/3\% membutuhkan penjelasan yang lebih dalam bahasa ibu mereka untuk mengerti informasi tersebut.47\% pasien tidak membaca formulir persetujuan tindakan.

Pre-Operasi merupakan tahapan awaldalam proses pembedahan yang dimulai daripra bedah (pre operasi), bedah (intra operasi),pasca bedah (post operasi) (Sujoyono \&Harmoko, 2012). Gambaran informed consent sebelum tindakan opeasi / pre-operasi idealnya dimulai ketika pasien diberitahukan pertama kali tentang perlunya operasi.Semakin lama waktu pasien harus bersiap-siap menghadapi operasi, secara fisik maupun secara emosional, semakin baik pasien untuk dapat menyesuaikan diri (Mary, 2014)

2. Hubungan sikap perawat Dengan Tingkat Kepuasan Keluarga Pasien Pre Operasi Rs TK II Pelamonia Makassar

Berdasarkan data analisis univariat diperoleh, dari 39 responden menunjukkan bahwa sikap perawat pada keluarga pasien pre operasi di ruang perawatan Rs TK II Pelamonia Makassar didapati bahwa dari sebagian besar secara baik maka diperoleh data bahwa responden yang merasa puas $(82,1)$ mayoritas didominasi oleh responden yang menilai sikap perawat Baik $(74,4)$, sementara yang menilai tingkat kepuasan Kurang hanya $(17,9)$ dengan menilai sikap perawat kurang $(25,6)$.

Hasil analisis Hubungan sikap perawat Dengan Tingkat Kepuasan Keluarga Pasien Pre Operasi Rs TK II Pelamonia Makassar dengan alat analisis korelasi chi-square diperoleh nilai $p$-value sebesar 0,000 dengan nilai kuefisien korelasi chi-square sebesar $<0,05$ dengan demikian terbukti, bahwa terdapat Hubungan sikap perawat Dengan Tingkat Kepuasan Keluarga Pasien Pre Operasi Rs TK II Pelamonia Makassar ( nilai $p$-value sebesar $0,000<0,05)$. Hal ini berarti semakin baik penilaian responden terhadap sikap perawat, maka semakin tinggi tingkat kepuasan keluarga pasien pre operasi, begitu pula sebaliknya (Sugiyono, 2006).

Sikap adalah respon tertutup seseorang terhadap stimulus atau objek tertentu, yang sudah melibatkan faktor pendapat dan emosi yang bersangkutan. Sikap merupakan kesiapan atau kesediaan untuk bertindak, dan bukan merupakan pelaksanaan motif tertentu. Dalam kata lain, sikap belum merupakan tindakan (reaksi terbuka) atau aktivitas. Akan tetapi merupakan predisposisi perilaku (tindakan), atau reaksi tertutup (Notoatmodjo, 2010).

Terbentuknya sikap positif dari perawat dapat dipengaruhi oleh interaksi antar sesama perawat, karena sikap terbentuk dengan interaksi terjadi saling tukar informasi mengenai hal yang berhubungan dengan pelaksanaan asuhan keperawatan. Perawat mau dan memperhatikan kebutuhan klien,mengerjakan dan menyelesaikan yang diberikan serta mengajak orang lain untuk mengerjakan atau mendiskusikan suatu masalah. Hal ini sesuai dengan teori tingkatan sikap yang diutarakan oleh Notoatmodjo (2007) yaitu sikap memiliki berbagai tingkatan, yang pertama menerima (receiving). Kedua merespon (responding), ketiga menghargai (valuing) dan terakhir bertanggung jawab (responsible). Pada dasarnya sikap perawat yang ditunjukkan sudah mencapai pada tingkatan bertanggung jawab (responsible) yaitu bertanggung jawabatas segala yang dipilinnya dengan segala resiko yang mungkin akan terjadi.

Terkait dengan permasalahanpermasalahan tersebut diatas maka langkah yang dapat diambil pihak manajemen rumah sakit adalah mengadakan pelatihan-pelatihan atau kepada setiap perawat, seperti pelatihan 
custamer care dan memberikan kesempatan perawat untuk melanjutkan pendidikan ke jenjang yang lebih tinggi, serta meningkatkan kesejahteraan perawat. Selain itu langkah lainnya adalah menegakkan disiplin terhadap perawat yang dinilai melanggar aturan kerja, seperti: menggunakan perlengkapan yang kurang bersih dalam melakukan pelayanan, baik melalui teguran, tertulis, maupun sangsi administratif lainnya.

\section{KESIMPULAN}

1. Ada hubungan Pemberian informed consent dengan tingkat kepuasan keluarga pasein pre operasi dalam pelayanan keperawatan di RS TK II Pelamonia Makassar.

2. Ada hubungan Sikap Perawat dengan tingkat kepuasan keluarga pasein pre operasi dalam pelayanan keperawatan di RS TK II Pelamonia Makassar.

\section{SARAN}

1. Bagi institusi pendidikan keperawatan Diharapkan agar hasil penelitian dapat dijadikan sebagai bahan informasi bagi institusi pendidikan.

2. Bagi profesi perawat Menambah pengetahuan dibidang keperawatan dalam rangka pengembangan profesi keperawatan.

3. Bagi tempat penelitian

Diharapkan agar hasil penelitian ini dapat dijadikan sebagai bahan acuan bagi petugas kesehatan dan masyarakat dalam meningkatkan derajat kesehatan.

4. Bagi peneliti kesehatan

Dapat memberi gambaran dan menambahkan sumber informasi bagi peneliti selanjutnya

\section{DAFTAR PUSTAKA}

Abdullah (2019). Pedoman Penulisan Skripsi. Makassar. Stikper Gunung Sari Makassar

Afriyanti, D. et al, (2014). Kualitas pelayanan keperawatan di Rumah Sakit Umum Daerah (RSUD) Tanjung Uban Profinsi Kepulauan Riau.

Agung, M et al (2016). Pengaruh Kualitas Pelayanan Keperawatan, Fasilitas, Dan Minat Pasien Terhadap Kepusan Pasien Di Ruangan Rawat Inap RSU Wisata UIT Makassar.

Dwi Jayanti (2016). Pengaruh Pemberian Informed Consent Terhadap Tingkat Kepuasan Pasien Pre Operasi Fraktur Di Ruang Mawar RSUD Dr Roehadi Prijonegore Sragen.

Fatkhul,M \& Jalal,A (2007). Hubungan Mutu Pelayanan Keperawatan Dengan Kepuasan Pasien Di Instlasi Rawat Inap RSUD Tugu Rejo Semarang.

Hasmi, (2016).Metode Penelitian Kesehatan. Kota Bogor. Penerbit In Media.

Hidayat, A.A (2011). Metode Penelitian Keperawatan dan Kebidanan Serta Teknik Analisis Data.Surabaya :SalembaMedika

Irwan (2017). Hubungan Informed Consent Dengan Kecemasan Pada Klien Pra Bedah Katarak Di Celebes Eye Center Makassar.

Khairun, A, R (2015). Perbedaan Caring Perawat pada kepuasan pasien igd dengan rawat inap kelas III RSUD Goeteng Taroenadibrata Purbalingga.

Nugrahaningsi, W dkk (2015). Hubungan Sikap Perawat Dengan Kepuasan Pasein Dalam Pelayanan Keperawatan Di Bangksal Pavilium RSUD Salatiga.

Nurhidaya, A (2014). Hubungan pelayanan keperawatan dengan kepuasan pasien rawat inap peserta jaminan kesehatan nasional (JKN) di Rumah Sakt Umum Daerah Labuang Baji Makassar.

Purwati, S (2017). Hubungan Pelayanan Perawat Dengan Kepuasan Pasien Rawat Jalan Di Puskesmas Wisata Dau Malang.

Triwibowo,C \& Fauziah, Y (2012). Makpraktik dan etika keperawatan, Yogyakarta : Nuha Medika.

Trivel, M (2013). Hubungan Antara Tingkat Kepuasan Pasien Terhadap Pemberian Informed Consent Sebelum Tindakan Operasi Di RSUD Dr Moewardi. 
Wulandari, N (2015). Hubugnan Layanan Keperawatan Dengan Tingkat Kepuasan Pasie Rawat Inap Di Rumah Sakit Umum Daerah (RSUD) Ungaran Semarang.

Yulia, M dkk (2015). Standar Mutu Pelayanan Keperawatan 